\title{
Two Cases of Contralateral Depressor Labii Inferioris Resection in Patients with Congenital Unilateral Lower Lip Paralysis
}

\author{
Myung Woo Kim, Byung Woo Lim, Hae Dong Kim, and Jin Kim \\ Department of Otorhinolaryngology-Head and Neck Surgery, Ilsan Paik Hospital, Inje University College of Medicine, Goyang, Korea
}

\author{
선천성 일측 하순 마비 환자의 건측 하순하제근 절제를 통한 안면 비대칭 치료 2예 \\ 김명우 · 임병우 · 김해동 · 김 진 \\ 인제대학교 의과대학 일산백병원 이비인후과학교실
}

\author{
Received March 24, 2016 \\ Revised May 22, 2016 \\ Accepted June 13, 2016 \\ Address for correspondence \\ Jin Kim, MD, PhD \\ Department of Otorhinolaryngology- \\ Head and Neck Surgery, \\ Ilsan Paik Hospital, Inje University \\ College of Medicine, \\ 170 Juhwa-ro, Ilsanseo-gu, \\ Goyang 10380, Korea \\ Tel $+82-31-910-7250$ \\ Fax $+82-31-910-7219$ \\ E-mail jinsound@gmail.com
}

Congenital unilateral lower lip paralysis (CULLP) is a rare condition characterized by inversion and absent depressive movement of the affected lower lip while moving the mouth, which is recognized when the infant cries. CULLP is a variation of facial paralysis caused by abnormal development of marginal mandibular nerve, hypoplasia of the depressor labii inferioris muscle or depressor anguli oris muscle. This report introduces two cases of congenital unilateral lower lip palsy, presenting a balancing technique involving the resection of the depressor labii inferioris on the non-affected side.

Korean J Otorhinolaryngol-Head Neck Surg 2017;60(9):463-6

Key Words Congenital $\cdot$ Facial palsy $\cdot$ Muscle denervation.

\section{서 론}

선천성 일측 하순 마비(congenital unilateral lower lip paralysis)는 일측 안면 마비 종류 중 하나로 매우 드물게 보고 된다. 이는 출생 시부터 일측 하순이 마비되어 안면 비대칭이 발생하는 질환으로 출생 후 울거나 웃는 표정을 지을 때 마비 가 있는 쪽 하순의 내림(depression)이 되지 않고 안으로 말 려 들어가는 양상을 보인다. 출생 시 발견된 하순 마비의 원 인은 출산에 의한 외상, 비정상 신경발달, 유전자 이상, 바이 러스 감염 등에 의한 하악신경(marginal mandibular nerve, $\mathrm{MMN}$ )마비 및 결손에 의하거나 구각하제근(depressor anguli oris muscle, DAO)이나 하순하제근(depressor labii inferioris

This is an Open Access article distributed under the terms of the Creative Commons Attribution Non-Commercial License (http://creativecommons.org/licenses/by-nc/4.0) which permits unrestricted non-commercial use, distribution, and reproduction in any medium, provided the original work is properly cited. muscle, DLI)발육부전에 의한다고 알려져 있다. ${ }^{1-3)}$ 하순을 움 직이고 양측의 대칭성을 유지하는 하순의 근육에는 입술을 아래로 당기는 구각하제근(DAO), 하순하제근(DLI), 이근(mentalis muscle), 광경근(platysma muscle)이 있으며 이 근육들의 길항근육으로 구륜근(orbicularis oris muscle)이 있다(Fig. 1). 이 근육들 중 하순하제근이 하순의 대칭성을 유지하는 데 가장 중요한 역할을 하는 것으로 알려져 있다. ${ }^{4)}$ 하순 내림을 담당하는 근육에 마비 혹은 결손이 발생하면 평상시 양측 하 순은 대칭적으로 보일 수 있으나 웃음을 지을 때 양측 하순의 비대칭은 더욱 두드러지게 나타나며 표정이 더욱 부자연스럽 게 된다.

선천성 일측 하순 마비를 치료하기 위한 방법으로는 현재 수술적 치료 또는 보톡스(OnabotulinumtoxinA) 주입을 시도 해 볼 수 있다. 선천성 일측 하순 마비 환자에서 하순하제근 절제를 시행한 국내 보고는 아직 없으며 저자는 하순하제근 
절제를 통하여 하순 비대칭을 교정하고 양호한 결과를 얻었 기에 치료에 관한 문헌 고찰과 함께 두 증례를 보고하고자 한다.

\section{증 례}

22세, 27세의 남자 환자로 출생 시 발생한 일측 하순 마비 를 주소로 내원하였다. 환자들은 출생 시 분만 손상 혹은 외 상력은 없었으며 진료 시 동반된 선천적 질환이나 기저질환 은 없었다. 신체 진찰 상 독립된 일측 하순의 마비를 보였으 며 다른 안면 근육의 마비증상 및 동반된 연합운동은 보이 지 않았다. 저자는 환자의 과거력과 신체진찰을 종합하여 선 천성 일측 하순 마비로 진단하였다.

환자들의 초기 치료로 비 침습적인 치료인 건측 하순의 보 톡스(Botox ${ }^{\circledR}$; Allergan, Inc., Irvine, CA, USA) 주입술을 시 행하였으며 시술 후 효과적인 양측 하순의 대칭을 보였으나 수개월 뒤 다시 하순 비대칭 소견을 보여 영구적인 교정을 위 한 건측 하순하제근 절제를 계획하였다. 수술 전 환자에게 하 순의 대칭성은 교정되나 근육 절제에 따른 건측 하순의 움직 임 저하를 설명하고 환자 동의 하에 수술을 진행하였다. 저자 는 하순하제근의 정확한 절제가 이루어 지도록 절제 범위를 정하여 하순을 촉진하고 하순하제근을 확인한 후 피부에 표 시하였다. 하순을 부드럽게 위로 당기면 하순의 중간과 외측 근육은 저항성이 낮으나 내측과 외측 $1 / 3$ 부위는 저항성이 느껴진다. 이 부위를 하순하제근이 있는 위치로 판단하고 수 술 부위 절제를 시행하기 전 1:100000 에피네프린이 함유된 $2 \%$ 리도카인을 절제할 근육에 주사하여 마취 및 하순 비대
칭이 교정됨을 확인하였다. ${ }^{5)}$ 절개는 구강 내로 점막을 절개하 였으며 하협전정(lower buccal vestibule)에서 상방 $0.5 \mathrm{~cm}$ 에 외측에서 중앙으로 절개를 가하였다. 이신경(mental nerve)이 손상되지 않도록 절개 및 박리를 시행하였다(Fig. 1). 구각하 제근(DAO)이 하순하제근(DLI)에 대각선으로 지나가는 것 을 확인하여 하순하제근의 위치를 재차 확인하고 하순하제 근을 완전히 절제하였다. 또한 절제 후 근육들의 재유착을 방지하기 위하여 유착방지제(Guardix-sol ${ }^{\circledR}$; Hanmi Pharm Co., Seoul, Korea) 를 절제부위에 도포하였다.

건측 하순하제근 절제 후 두 명의 환자 모두 하순의 비대 칭이 교정되었다(Fig. 2) 수술 후 각각 10 개월, 12 개월 동안 외래 경과관찰 하였으며 현재까지 재발 없이 유지되었다. 두 환자 모두 하순하제근 절제 후 웃거나 슬픈 표정을 지을 때 양측 하순의 움직임이 저하되어 감정 표현에 약간 부자연스 러운 모습을 보였으나 비대칭에 의한 일그러진 하순의 움직 임보다 미용적으로 우수하며 환자들의 만족도 또한 매우 높 았다. 또한 수술 후 발음장애 혹은 식이 불편을 호소한 환자 는 없었다.

\section{고 찰}

선천성 일측 하순 마비는 하악신경(MMN) 마비 및 결손 에 의하거나 구각하제근(DAO)이나 하순하제근(DLI)의 발 육부전에 의한다고 알려져 있다. 이러한 일측 하순 마비로 인한 하순의 비대칭을 교정하기 위하여 많은 수술 법들이 과 거부터 시도되어 왔다. 이는 선천성 질환에만 국한된 수술법 은 아니며 외상 및 후천성 안면마비로 인한 하순 비대칭을
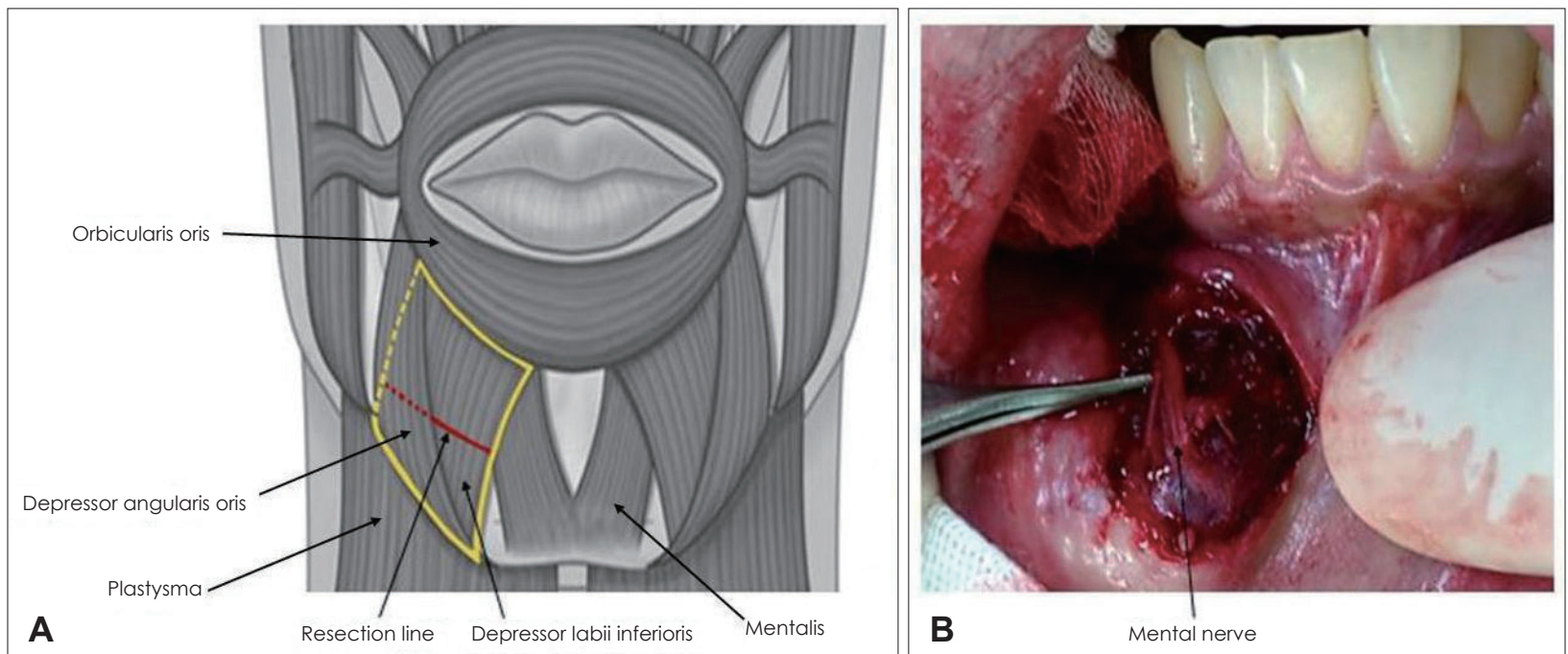

Fig. 1. Anatomy of lower lip depressor muscles. Yellow line shows the range of the depressor labii inferioris muscle and red line shows the muscle resection range (A). Depressor labii inferioris muscle was resected by blunt Metzenbaum scissors. Mental nerve branches were identified and preserved $(B)$. 

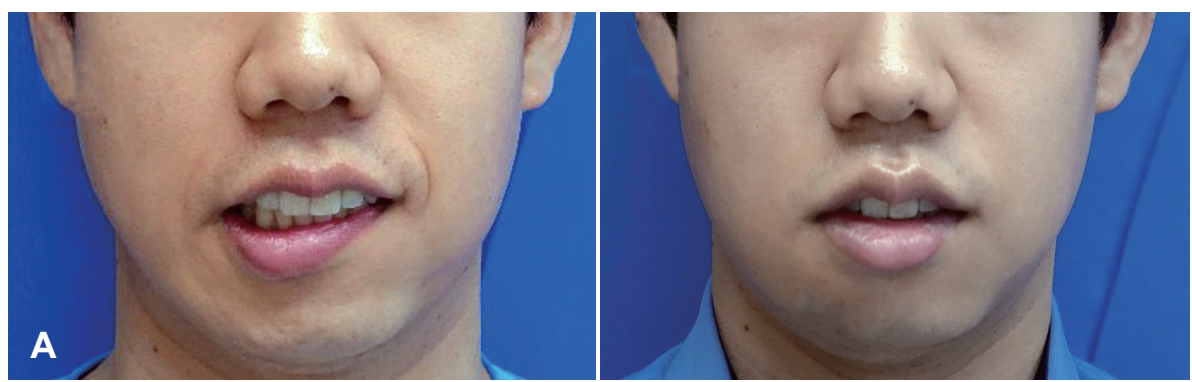

Fig. 2. A patient with isolated left lower lip paralysis showing asym-
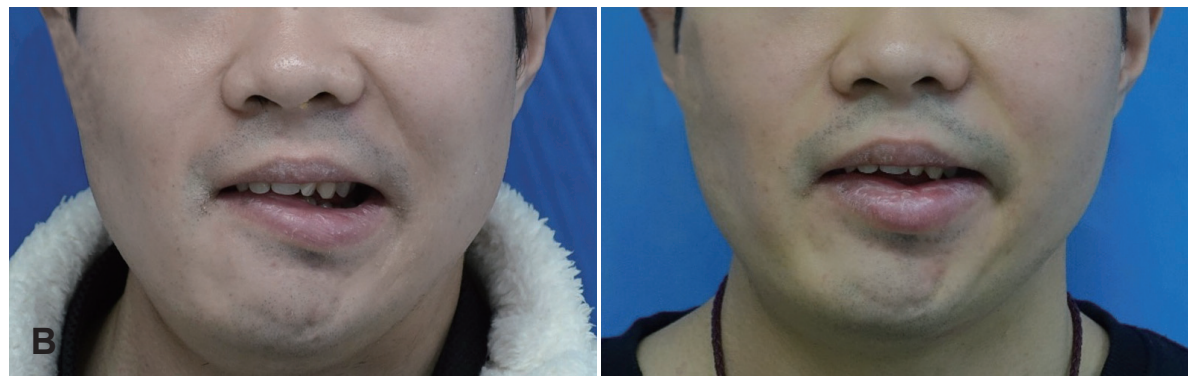
metry of the lower lip when smiling. Following a resection of the muscle belly of the right depressor labii inferioris. The lower lip is now symmetrical for 10 month after surgery (A). A patient with isolated right lower lip paralysis showing asymmetry of the lower lip when smiling. Following a resection of the muscle belly of the left depressor labii inferioris. The lower lip is symmetrical for one year after surgery $(B)$.

교정하기 위한 치료 방법으로도 사용되고 있다.

하순의 비대칭을 교정하기 위한 치료로는 침습적 치료와 비 침습적 치료로 나뉜다. 비침습적 치료는 보톡스(BTX-A)를 이용하여 안면 비대칭을 교정하는 방법으로 건측 하순에 보 톡스를 주입한다. ${ }^{6}$ 보톡스는 일시적으로 건측 하순의 근육 작용을 억제시켜 양측 하순의 대칭을 유도하는 방법으로 어 렵지 않게 시술할 수 있으나 수개월 후 반복적 주입이 필요하 다는 단점이 있다. 침습적 치료는 수술로 하순을 교정하는 방 법이며 마비가 있는 하순에 수술하는 방법과 마비가 없는 하 순에 수술하는 방법으로 나뉜다. 마비가 있는 하순에 수술하 는 방법으로는 교차안면신경 이식술(cross facial nerve graft) 및 신경 교차술(nerve crossover) 그리고 근 전위술(muscle transfer)을 이용한 방법이 있다. 비복신경(sural nerve)을 이 용하여 교차 안면신경 이식술을 시행할 수 있으멱) 신경 교차 술은 설하 신경(hypoglossal nerve)을 이용하여 하순을 재건 하는 방법이다. ${ }^{8)}$ 근 전위술은 이복근의 전복(anterior belly of digastric muscle)을 구륜근(orbicularis oris muscle)에 걸 어주거나 ${ }^{9,10)}$ 대퇴근막을 이용하여 정적 재건술을 시행하기 도 한다. ${ }^{11)}$ 하지만 이러한 수술들은 전신마취가 필요하며 수 술 후 연관된 근육들의 합병증이 병발할 수 있고 수술 시간 이 길다는 단점들이 있어 흔히 사용되지 않는다. 마비가 없 는 하순을 수술하는 방법은 하순 내림에 작용하는 근육들 을 절제하여 양측 하순의 대칭을 맞춰주는 것으로 안전하게 시행할 수 있다. ${ }^{12)}$ 그 외에도 건측의 하악신경이나 구륜근을 절단하는 수술 방법도 있으나 구륜근이 약화되어 구강 실금 (oral incontinence)이 발생할 위험이 높다. 반면 하순하제근 절제는 국소 마취제를 절제할 근육에 주입하여 수술 후 결 과를 미리 예측할 수 있으며 다른 안면 재건술과 달리 수술
의 범위가 작고 심각한 부작용이 발생하지 않는다는 장점이 있으며 수술 후 효과가 즉시 나타나며 영구적인 결과를 얻을 수 있다. 따라서 저자는 선천성 일측 하순 마비 환자에게 양 측 하순의 대칭성을 유지하는 방법으로 국소마취 하에 마비 가 없는 하순의 하순하제근 절제를 시행하였고 합병증 없이 우수한 결과를 얻었다. 하순하제근 절제술을 시행 후에 하순 의 움직임이 일부 저하되어 표정의 어색함은 있으나 하순의 비대칭이 교정되었고 환자들의 만족도 또한 높았다. 특히 수 술 후 결과를 두려워하는 환자들에게서 수술 전 하순하제근 에 국소 마취제를 주입하여 하순 비대칭의 교정을 확인한 후 에 수술할 수 있어 수술 후 결과를 환자가 미리 예측할 수 있 다는 점 또한 장점으로 판단된다. 본 증례와 같이 선천성 일 측 하순 마비 환자뿐만 아니라 만성 안면마비 환자에서 하순 의 비대칭이 심한 경우 하순하제근 절제를 시행하여 우수한 결과를 얻어낸 보고가 있으며 ${ }^{13)}$ 저자의 경험에 따른 결과 또 한 수술 후 결과가 대체적으로 우수하였다.

하순하제근 절제는 안전한 수술 방법이나 재발 및 합병증 예방을 위한 주의점들이 있다. 첫째로 이신경(mental nerve) 를 명확하게 찾고 손상 없이 보존해야 한다. 턱끝신경이 손상 받게 되면 하악의 감각저하가 지속되어 수술 후 만족도를 저 하시키는 요인이 된다. 둘째로 하순하제근을 정확히 찾고 근 육을 완전히 절제하여야 한다. 특히 건측 하순하제근이 불완 전하게 절제될 경우 절제된 근육섬유들의 유착이 생겨 하순 비대칭이 다시 발생할 수 있다. 위 두 가지를 주의하여 수술 하면 합병증 없이 성공적인 수술을 얻어낼 수 있을 것이다. 저자는 선천 일측 하순 마비 환자에서 건측 하순하제근 절 제를 시행하였으며 부작용 없는 우수한 결과를 경험하였기 에 본 증례를 보고하는 바이다. 


\section{REFERENCES}

1) Nelson KB, Eng GD. Congenital hypoplasia of the depressor anguli oris muscle: differentiation from congenital facial palsy. J Pediatr 1972;81(1):16-20.

2) Verzijl HT, van den Helm B, Veldman B, Hamel BC, Kuyt LP, Padberg $\mathrm{GW}$, et al. A second gene for autosomal dominant Möbius syndrome is localized to chromosome 10q, in a Dutch family. Am J Hum Genet 1999;65(3):752-6.

3) Puñal JE, Siebert MF, Angueira FB, Lorenzo AV, Castro-Gago M. Three new patients with congenital unilateral facial nerve palsy due to chromosome 22q11 deletion. J Child Neurol 2001;16(6):450-2.

4) Lockhart RD, Hamilton GF, Fyfe FW. Anatomy of the human body. Philadelphia: JB Lippincott;1969.

5) Godwin Y, Tomat L, Manktelow R. The use of local anesthetic motor block to demonstrate the potential outcome of depressor labii inferioris resection in patients with facial paralysis. Plast Reconstr Surg 2005;116(4):957-61.

6) Clark RP, Berris CE. Botulinum toxin: a treatment for facial asymmetry caused by facial nerve paralysis. Plast Reconstr Surg
1989;84(2):353-5

7) Anderl H. Cross-face nerve transplant. Clin Plast Surg 1979;6(3): 433-49.

8) Koh KS, Kim J, Kim CJ, Kwun BD, Kim SY. Hypoglossal-facial crossover in facial-nerve palsy: pure end-to-sideanastomosis technique. Br J Plast Surg 2002;55(1):25-31.

9) Conley J, Baker DC, Selfe RW. Paralysis of the mandibular branch of the facial nerve. Plast Reconstr Surg 1982;70(5):569-77.

10) Tan ST. Anterior belly of digastric muscle transfer: a useful technique in head and neck surgery. Head Neck 2002;24(10):947-54.

11) Liu YM, Sherris DA. Static procedures for the management of the midface and lower face. Facial Plast Surg 2008;24(2):211-5.

12) Chen CK, Tang YB. Myectomy and botulinum toxin for paralysis of the marginal mandibular branch of the facial nerve: a series of 76 cases. Plast Reconstr Surg 2007;120(7):1859-64.

13) Hussain G, Manktelow RT, Tomat LR. Depressor labii inferioris resection: an effective treatment for marginal mandibular nerve paralysis. Br J Plast Surg 2004;57(6):502-10. 